\title{
The influence of biofungicide and chemical fungicides on the manifestation of diseases and the yield of soybeans
}

\author{
Svetlana Rezvyakova ${ }^{1, *}$, Leonid Eremin ${ }^{1}$, Petr Matveychuk ${ }^{1}$, and Elena Mitina ${ }^{1}$ \\ ${ }^{1}$ Oryol State Agrarian University named after N.V. Parakhin, 302019 Russia, Oryol, Generala Rodina Str., 69
}

\begin{abstract}
This study aims to improve the technology for protecting soybeans from fungal diseases based on new fungicides. The relevance of research is specified by a significant increase in the area occupied by soybeans and the need to protect crops from diseases. The experimental site is located in the territory of Oryol State Agrarian University (Lavrovo village of Oryol Region, Russia). The crop rotation is grainfallow, the predecessor is winter wheat. The soil type is dark gray forest medium loamy. Soil acidity is 5.7. It has the following content of macronutrients: $11.5 \mathrm{mg} / 100 \mathrm{~g}$ of soil for P2O5, $10.9 \mathrm{mg} / 100 \mathrm{~g}$ of soil for $\mathrm{K} 2 \mathrm{O}, 4.1 \%$ for humus. The Mezenka soybean was used, seeds of the 1st reproduction. Planting was carried out in the first decades of May 2019 and 2020. We used the Maksim, KS protectant (Fludioxonil, $25 \mathrm{~g} / 1$ ). Fungicides Propuls, SE (Prothioconazole, 125 g/l, Fluopyram, 125 g/l), Vintazh, ME (Difenoconazole, 65 $\mathrm{g} / \mathrm{l}$, Flutriafol, $25 \mathrm{~g} / \mathrm{l}$ ) and biofungicide Vitaplan, SP (Bacillus subtilis strain VKM-V-2604D, titer 1010 CFU/g and Bacillus subtilis strain VKM-B-2605D, titer $1010 \mathrm{CFU} / \mathrm{g}$ ) were used to treat plants at the end of June in the branching phase and again two weeks later in July in the budding phase. The treatment of soybean seeds with the fungicide Maksim, KS helped to protect the crop from fungal diseases until the first ten days of July. Two-fold treatment of crops with biofungicide Vitaplan and chemical fungicides Propuls and Vintazh had a significant impact on the prevalence and development of fungal diseases. The biological effectiveness of chemical fungicides in comparison with biological was higher in the phase of complete formation of beans - the beginning of ripening by 9 and $15 \%$, respectively. In comparison with the control, the increase in the yield of soybeans was $10.4 \%$ using Vitaplan, $16.4 \%$ using Propuls, $17.9 \%$ using Vintazh.
\end{abstract}

\section{Introduction}

In world agriculture, soybeans occupy the fourth place after wheat, corn, and rice, and the first place among grain legume crops. The unique composition of organic, mineral, biologically active substances, and their functional properties determine the versatility of application of this crop [1-3]. The total content of protein and fat in seeds reaches $70 \%$. Soybean grain contains up to $43 \%$ of protein, $18-20 \%$ of carbohydrates, and up to $25 \%$ of oil. The soy protein in terms of composition and quantitative content of essential amino acids belongs to complete proteins and in terms of biological value is close to meat proteins. Such a balanced composition has a positive effect on the metabolism and maintenance of human health [4-6].

The symbiotic nitrogen fixation is responsible for the indisputable agrotechnical value of soybeans [7-9]. The main area of soybean cultivation in Russia is the Amur Region and the Krasnodar Territory. Recently, there has been a significant increase in interest in the cultivation of soybeans in the Northwest, Central, and Central Black Earth Regions of Russia, including the Oryol Region [10-12].

The relevance of this research is explained by a sharp increase in the area occupied by soybeans in the Oryol
Region. In 2001-2006, the total area occupied by this crop in the Region was insignificant and did not exceed 0.7 thousand hectares (from 0.08 to 0.7 thousand hectares). In 2010 this indicator increased to 15.5 ths. hectares, in 2013 it exceeded 26 ths. hectares. In 2020, the area increased to 121.4 thousand hectares. This is primarily explained by the emergence of new, early, high-yielding and technological varieties of soybeans adapted to local conditions. The early-ripening varieties Mezenka, Svapa, Lantsentnaya and others, which mature stably in the conditions of the Oryol Region, are quite suitable for cultivation not only in its southern but also in the northern and central regions. They have a high productivity potential, are technologically advanced and resistant to abiotic environmental factors. These varieties now occupy the main areas of soybean cultivation in the Oryol Region, their primary seed production has been organized [13-15].

This work aims to improve the technology for protecting soybeans from fungal diseases using the new fungicides.

\footnotetext{
* Corresponding author: lana8545@yandex.ru
} 


\section{Materials and methods}

The experimental site used the grain-fallow crop rotation, the predecessor was winter wheat. The experimental site was located in the territory of Oryol State Agrarian University (Lavrovo village of Oryol Region, Russia). The soil type was dark gray forest medium loamy. Soil acidity was 5.7. It had the following content of macronutrients: $11.5 \mathrm{mg} / 100 \mathrm{~g}$ of soil for $\mathrm{P}_{2} \mathrm{O}_{5}, 10.9 \mathrm{mg} / 100 \mathrm{~g}$ of soil for $\mathrm{K}_{2} \mathrm{O}, 4.1 \%$ for humus. Soybean variety Mezenka was used, seeds of the 1st reproduction. The pickled seeds were sowed on 10 May 2019 and 2020. We used the Maksim, KS protectant (Fludioxonil, $25 \mathrm{~g} / \mathrm{l}$ ).

Fungicides Propuls SE, Vintazh ME, and biofungicide Vitaplan SP (Table 1) were used to treat the plants at the end of June in the branching phase and again two weeks later in July in the budding phase.

The meteorological conditions on the day of treatment were as follows: temperature $+20-24{ }^{\circ} \mathrm{C}$, humidity $40-48 \%$, cloudiness $1-2$ points, wind speed of 4-5 $\mathrm{m} / \mathrm{s}$. There was no precipitation. The degree of development and damage to soybean crops by diseases, as well as the biological effectiveness of the use of fungicides were estimated in accordance with the generally accepted method. Soybeans were harvested on 28 September 2019 and 22 September 2020.

Table 1. Characteristics of fungicides and methods of its application.

\begin{tabular}{|c|c|c|}
\hline $\begin{array}{c}\text { Fungicide, its active } \\
\text { ingredient and action } \\
\text { mechanism }\end{array}$ & $\begin{array}{l}\text { Diseases } \\
\text { affected by } \\
\text { the fungicide }\end{array}$ & $\begin{array}{c}\text { Dosage and } \\
\text { application } \\
\text { features }\end{array}$ \\
\hline $\begin{array}{l}\text { Vitaplan, SP (titer } 10+10 \\
\text { CFU/g) Bacillus subtilis. } \\
\text { Strain VKM-B-2604D + } \\
\text { Bacillus subtilis. Strain } \\
\text { VKM-B-2605D. }\end{array}$ & $\begin{array}{l}\text { Fusarium root } \\
\text { rot, } \\
\text { septoriasis, } \\
\text { ascochitosis, } \\
\text { peronoso- } \\
\text { porosus, } \\
\text { bacteriosis }\end{array}$ & $\begin{array}{l}\text { Spraying } 20- \\
40 \mathrm{~g} / \mathrm{ha}, 200 \\
\text { 1/ha of water }\end{array}$ \\
\hline $\begin{array}{l}\text { Propuls, SE Fluopyram }+ \\
\text { Prothioconazole }(125+125 \\
\text { g/l). The drug has a } \\
\text { systemic effect. }\end{array}$ & $\begin{array}{l}\text { Cercosporosis, } \\
\text { ascochitosis, } \\
\text { anthracnose, } \\
\text { septoria, } \\
\text { fusaritosis }\end{array}$ & $\begin{array}{l}\text { Dosage } 0.8-1 \\
\text { 1/ha, } 2001 / \text { ha } \\
\text { of water }\end{array}$ \\
\hline $\begin{array}{l}\text { Vintazh, ME Difenocon-zol } \\
+ \text { Flutriafol }(65 \mathrm{~g} / \mathrm{L}+25 \\
\mathrm{g} / \mathrm{L}) . \text { The drug has a } \\
\text { systemic effect. }\end{array}$ & $\begin{array}{l}\text { Ascochitis, } \\
\text { anthracnose, } \\
\text { septoria, } \\
\text { fusarium }\end{array}$ & $\begin{array}{l}\text { Dosage } 0.6- \\
0.8 \text { 1/ha, } 200 \\
\text { 1/ha of water }\end{array}$ \\
\hline
\end{tabular}

Fungicide treatment was carried out with a back-pack sprayer. The first one took place in the branching phase (the third triple leaf is out), the second one was in the budding phase. Each of the processed plots had a size of $52 \mathrm{~m}^{2}$.

The crop disease prevalence was established by examining the plots and counting the number of plants with signs of diseases and indicating the type of disease. To assess the degree of disease development, a combined percentage-point scale was used: 0 - no disease; 1 - up to $10 \%$ of the surface is affected; 2 - from 1 to $25 \% ; 3$ - from 26 to $50 \% ; 4$ - over $50 \%$ of the surface. For sampling, a $0.5 \times 0.5=0.25 \mathrm{~m}^{2}$ frame was used.

\section{Results and discussion}

The crop disease prevalence was assessed at the end of June in the branching phase (the third triple leaf is out), in the 3rd decade of July in the phase of the beginning of the formation of beans, and in early September in the phase of complete formation of beans, ripening. The diseased plants were counted from ten samples tested on each plot of the experiment. The general patterns of manifestation of soybean diseases in the 2019 and 2020growing seasons depending on the use of protective equipment are shown in Tables 2-4 and Figures 1-3.

The influence of biopreparation and fungicides on the manifestation of soybean diseases was considered against the background of the use of the seed protectant Maksim, KS, which can significantly reduce the manifestation of crop diseases, especially in the initial period of growth. Therefore, fusarium was the only registered disease in the branching phase "the third triple leaf is out".

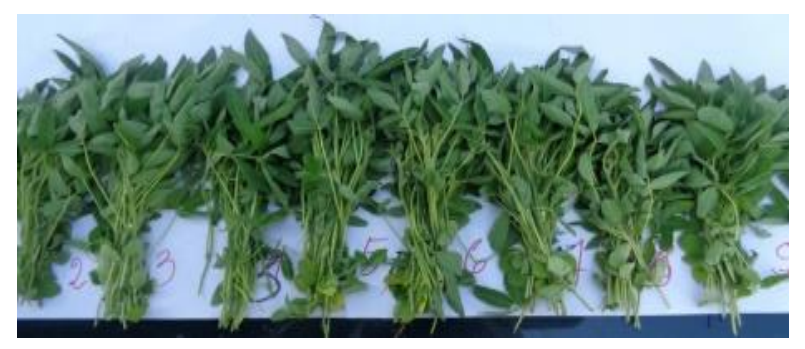

Fig. 1. General view of soybean plants by options (19 June 2020).

Examination of the development of diseases in the phase of bean formation was carried out in favorable weather conditions. The precipitation of June could provoke the spread and development of diseases, but subsequent dry weather held back their manifestations. The development of the disease was minimal and did not exceed one point. Therefore, we examined only the disease prevalence.

The results of the accounting showed that the control option had the highest percentage of the disease prevalence $-22.7 \%$. For the plants treated by Vitaplan biofungicide this indicator decreased by $10.4 \%$. For the plants treated by chemical fungicides Propuls and Vintazh it decreased by 11.7 and $12.0 \%$, respectively (Table 2). The biological effectiveness of the biopreparation was $45.8 \%$, for the chemical fungicides it was $5.7-7.1 \%$ higher. 
Table 2. Prevalence of soybean diseases due to fungicide use (phase of the beginning of bean formation), 3rd decade of July.

\begin{tabular}{|c|c|c|c|c|c|}
\hline Option & $\begin{array}{c}\text { Total } \\
\text { number } \\
\text { of } \\
\text { plants } \\
\text { per 0.5 } \\
\mathrm{m}^{2} \text { pcs. }\end{array}$ & $\begin{array}{c}\text { Number } \\
\text { of plants } \\
\text { affected } \\
\text { by } \\
\text { fusarium, } \\
\text { pcs. }\end{array}$ & $\begin{array}{c}\text { Number of } \\
\text { plants } \\
\text { affected by } \\
\text { ascochitosis, } \\
\text { pcs. }\end{array}$ & $\begin{array}{c}\text { Prevalence } \\
\text { of } \\
\text { diseases, } \\
\%\end{array}$ & $\begin{array}{c}\text { Biological } \\
\text { effectiveness } \\
\text { of }\end{array}$ \\
fungicides, $\%$ \\
\hline Control & 16 & 1.7 & 1.7 & 22.7 & \\
\hline Vitaplan SP & 16.3 & 0.7 & 1.3 & 12.3 & 45.8 \\
\hline Propuls SE & 15.3 & 1.0 & 0.7 & 11.0 & 51.5 \\
\hline Vintazh ME & 16 & 1.0 & 0.7 & 10.7 & 52.9 \\
\hline
\end{tabular}

Figure 2 shows that the lower leaves are individually affected by ascochitosis, and the roots are partly affected by Fusarium. The manifestation of downy mildew (peronosporosis) due to dry weather during this period was not observed.

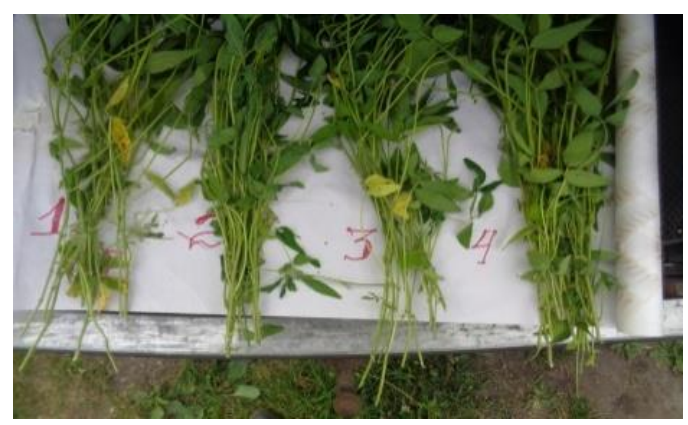

Fig. 2. The affection of soybeans by fungal diseases (ascochitis, peronospora, fusarium), 22 July 2020.

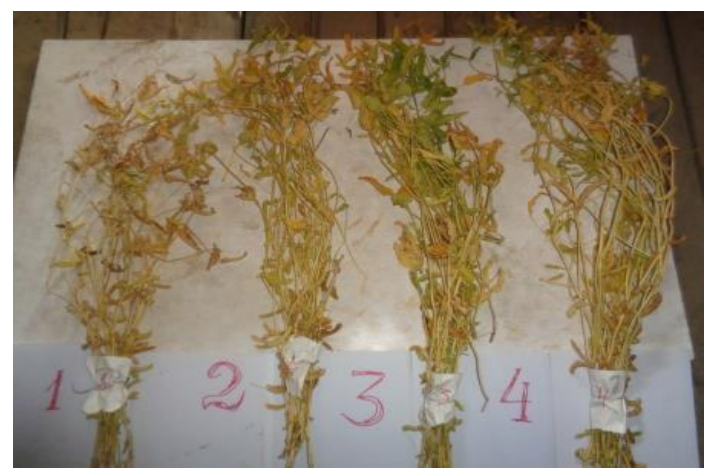

Fig. 3. The affection of soybeans by fungal diseases (ascochitis, peronospora, fusarium), 3 September 2020.

Table 3 presents the results of studies on the development of fungal diseases in early September 2020.

Table 3. Development of fungal diseases on soybean plants in the phase of complete formation of beans - the be-ginning of ripening, 3 September 2020.

\begin{tabular}{|l|c|c|c|c|}
\hline Option & $\begin{array}{c}\text { Total } \\
\text { number } \\
\text { of plants } \\
\text { per } \mathrm{m}^{2}, \\
\text { pcs. }\end{array}$ & $\begin{array}{c}\text { Number of } \\
\text { deseased } \\
\text { plants per } \\
\mathrm{m}^{2}, \text { pcs. }\end{array}$ & $\begin{array}{c}\text { Prevalence } \\
\text { of diseases } \\
\%\end{array}$ & $\begin{array}{c}\text { Biological } \\
\text { effectiveness of } \\
\text { fungicides, \% }\end{array}$ \\
\hline Control & 33 & 27 & 81.8 & \\
\hline Vitaplan SP & 33 & 24 & 72.7 & 26 \\
\hline Propuls SE & 34 & 22 & 64.7 & 35 \\
\hline Vintazh ME & 34 & 20 & 58.8 & 41 \\
\hline
\end{tabular}

Against the background of treatment with the biopreparation Vitaplan, the development of diseases was $72.7 \%$, the biological efficiency was $26 \%$. The treatment of crops with chemical fungicides was more effective in comparison with the biopreparation by 8.0 and $13.9 \%$. With the use of Propuls and Vintazh, the prevalence of diseases decreased by 17.1 and $23.0 \%$ compared with the control option. The biological effectiveness of these chemical fungicides in comparison with biological was higher by 9 and $15 \%$, respectively.

Despite favorable weather conditions in terms of inhibiyion the development of diseases, fungicides have played an important role in protecting soybean crops from fungal diseases. During the entire growing season, fungicides protected against the prevalence of diseases, and only in the phase of bean formation, due to cold weather, fungal infections began to actively develop.

Analysis of the yield structure in different phases of development and registering the yield of soybeans showed that Vitaplan biopreparation, despite the positive protective effect, did not have a significant effect on the studied trait. Its yield was at the level of the control option. Table 4 shows the structure of the soybean yield in the complete ripening phase.

The control and other options significantly varied in the number of beans, seeds, weight of 1000 seeds, weight of seeds per plant, and yield. According to these indicators, the best results were achieved by options using Propuls and Vintazh chemical fungicides. Against the background of a positive protective effect on soybean crops, Propuls and Vintazh fungicides provided an increase in yield by 3.63 and $3.96 \mathrm{c} /$ ha compared to the control. In accordance with the modern requirements for the biologization of agricultural production, the use of Vitaplan biopreparation is relevant, which also provided an increase in soybean yield by $2.29 \mathrm{c} / \mathrm{ha}$.

Table 4. Soybean yield structure (complete ripening phase), 2019-2020.

\begin{tabular}{|c|c|c|c|c|c|}
\hline Option & $\begin{array}{c}\text { Number of } \\
\text { beans per } \\
\mathbf{1} \text { plant, } \\
\text { pcs. }\end{array}$ & $\begin{array}{c}\text { Number of } \\
\text { seeds per 1 } \\
\text { plant, pcs. }\end{array}$ & $\begin{array}{c}\text { Weight } \\
\text { of 1000 } \\
\text { seeds, g }\end{array}$ & $\begin{array}{c}\text { Weight } \\
\text { of seeds, } \\
\text { glant }\end{array}$ & $\begin{array}{c}\text { Soybean } \\
\text { yield, } \\
\text { c/ha }\end{array}$ \\
\hline Control & 25.0 & 40.0 & 168.4 & 6.7 & 22.11 \\
\hline $\begin{array}{c}\text { Vitaplan } \\
\text { SP }\end{array}$ & 25.2 & 43.0 & 170.2 & 7.4 & 24.40 \\
\hline $\begin{array}{c}\text { Propuls } \\
\text { SE }\end{array}$ & 27.0 & 45.2 & 171.6 & 7.8 & 25.74 \\
\hline $\begin{array}{c}\text { Vintazh } \\
\text { ME }\end{array}$ & 28.1 & 45.7 & 172.2 & 7.9 & 26.07 \\
\hline $\mathrm{HCP}_{05}$ & - & 2.47 & 1.68 & 0.58 & 1.31 \\
\hline
\end{tabular}

\section{Conclusion}

1. Treatment of soybean seeds with the fungicide Maksim KS in both years of study helped to protect the crop from fungal diseases until the first ten days of July.

2. Two-fold treatment of crops with biofungicide Vitaplan and chemical fungicides Propuls and Vintazh had a significant impact on the prevalence and development of fungal diseases. Thus, the biological effectiveness of chemical fungicides in comparison with 
biological was higher in the phase of complete formation of beans - the beginning of ripening by 9 and $15 \%$, respectively.

3. In comparison with the control, the increase in the yield of soybeans was $10.4 \%$ when using Vitaplan preparation, $16.4 \%$ for Propuls, $17.9 \%$ for Vintaz.

\section{References}

1. M.M. Brooks, Soybean protein fibres - past, present and future, Wood head publishing series in textiles, Biodegradable and sustainable fibres (Cambridge, 2005, 398-440) DOI: 10.1533/9781845690991.398

2. N.I. Zaitsev, N.I. Bochkarev, S.V. Zelentsov, Prospects and directions of soybean breeding in Russia in the context of the implementation of the national strategy of import substitution, Oil crops, 2 (166), 3-11 (2016)

3. B. Stobaugh, L. Florez-Palacios, P. Chen, M. Orazaly, Agronomic evaluation of high-protein and high-oil soybean genotypes for specialty markets, Journal of Crop Improvement, 31 (2), 247-260 (2017) DOI: 10.1080/15427528.2017.1287807

4. J. Yavelow, T.H. Finlay, A.R. Kennedy, W. Troll, Bowman-Birk soybean protease inhibitor as an anticarcinogen, Cancer Res., 43 (5 Suppl), 24542459 (1983)

5. R.F. Wilson, Seed composition, Soybeans: improvement, production and uses, American Society of Agronomy, Crop Science Society of America, and Soil Science Society of America (Madison, Wisconsin, USA, 2004, 621-677)

6. H. Kobayashi, Prevention of cancer and inflammation by soybean protease inhibitors, Front. Biosci., 5, 966-73 (2013) DOI: 10.2741/E676

7. J. Clúa, C. Roda, M.E. Zanetti, F.A. Blanco, Compatibility between legumes and rhizobia for the establishment of a successful nitrogen-fixing symbiosis, Genes (Basel), 9 (3), 125 (2018) DOI: 10.3390/genes9030125

8. A.M.K. Al-Falih, Factors affecting the efficiency of symbiotic nitrogen fixation by Rhizobium, Pakistan Journal of Biological Sciences, 5 (11), 1277-1293 (2002) DOI: 10.3923/pjbs.2002.1277.1293

9. Yu.V. Kosulnikov, Yu.V. Laktionov, On the factors affecting the toxicity of seed protectants for symbiotic nitrogen fixers as part of biopreparations, Agricultural biology, 53 (5), 1037-1044 (2018) DOI: 10.15389/agrobiology.2018.5.1037

10. I.V. Seferova, T.V. Misyurina, M.A. Nikishkina, Ecological and geographical assessment of the biological potential of early maturing varieties and soybean seeding, Agricultural biology, 5, 4247 (2007)

11. M. Vishnyakova, I.V. Seferova, Soybean genetic resources for production in the Non-Black Earth Zone of the Russian Federation, Legume prospects (The journal of the International Legume Society, Novi Sad, Serbia), 1, 7-9 (2013)

12. I.V. Seferova, Soybeans in the North-West of the Russian Federation, Oil crops, 3 (167), 101-105 (2016)

13. A.A. Ivanova, I.Yu. Fadeev, The influence of weather conditions on the yield of soybeans in the Volga-Vyatka Region, The All-Russia Research and Trade journal "Legumes and groat crops", 4 (36), 93-98 (2020) DOI: $10.24411 / 2309-348 X-$ 2020-11210

14. V.N. Zaitsev, A.I. Zaitseva, V.I. Mazalov, New soybean variety Shatilovskaya 17, The All-Russia Research and Trade journal "Legumes and groat crops", 3 (35), 73-77 (2020) DOI: 10.24411/2309-348X-2020-11188

15. E.V. Golovina, V.I. Zotikov, Production process and adaptive responses to abiotic factors of soybean varieties of the northern ecotype in the Central Black Earth Region of the Russian Federation (Oryol, 2019, 318) 